\title{
Constructing Memory through Television in Argentina
}

\author{
by \\ Claudia Feld \\ Translated by \\ Victoria J. Furio
}

\begin{abstract}
Television represents Argentina's recent past through three specific links with social memory: as an "entrepreneur of memory," shaping public agendas, as a vehicle of intergenerational transmission of past events, and as a creator of meaning through images, sounds, and words, a "stage for memory." An analysis in terms of the links between television and the memories constructed around the forced disappearance of persons during the 1976-1983 military dictatorship reveals the complex way in which the obstacles when narrating an extreme experience are combined with the attempt to sell a product and entertain the spectator.
\end{abstract}

La televisión representa el pasado reciente de la Argentina a través de vínculos específicos con la memoria social: como un "emprendedor de la memoria" definiendo las agendas públicas, como un vehículo de transmisión intergeneracional sobre el pasado y como un creador de significados por medio de imágenes, sonidos y palabras, esto es, un "escenario para la memoria." Un análisis de los vínculos entre televisión y memorias, construido alrededor de la desaparición forzada de personas durante la dictadura militar de 1976 a 1983, revela la manera compleja en la cual los obstáculos para relatar ese periodo trágico se combinan con el intento de vender un producto y entretener al espectador.

Keywords: Memory, Television, Image, Dictatorship, Argentina

The last military dictatorship in Argentina remained in power from 1976 to 1983. Although there had been other military governments before it, the repression carried out by this regime was unprecedented in both its magnitude and the principal method it employed: the forced disappearance of persons. This method consisted of kidnapping, torture, and detention in clandestine prisons, followed by the murder and concealment of the bodies of thousands of opponents (Calveiro, 1998). In the years following the dictatorship, the crime of disappearance produced specific challenges for collective memory and recent history in Argentina. Within the overall dilemma of handling that past, the problem arose of how to represent that "extreme experience" (Pollak and Heinich, 1986) - what scenarios and spaces could display those narratives, what languages could transmit them appropriately. Clearly, this was not the

Claudia Feld is a researcher at the Consejo Nacional de Investigaciones Científicas y Técnicas and director of the Núcleo de Estudios sobre Memoria of the Instituto de Desarrollo Económico Social in Buenos Aires. She is the author of Del estrado a la pantalla: Las imágenes del juicio a los ex comandantes en Argentina (2002) and coeditor (with Jessica Stites-Mor) of El pasado que miramos: Memoria e imagen ante la historia reciente (2009). Victoria J. Furio is a translator in New York City. 
first time that collective memory or the writing of history had faced this problem. Many of these questions had generated debates and reflections in various societies, particularly those that had gone through the experience of World War II and the Holocaust. In many of these debates, the main concerns centered on the appropriate language for depicting the unimaginable through art, the challenges posed by representing horror in historical narratives, and the difficulties for witnesses in recounting that past (see, for example, Baer, 2006; Friedlander, 1992; Huyssen, 2002; Koch, 1990; LaCapra, 2009). When this concern extended to the audiovisual media, it was film, documentary as well as fiction, that piqued the interest of many researchers (among many others, Delage, 2007; Drame, 2007; Hansen, 2001; Insdorf, 1985; Kaes, 1989).

Analyzing how extreme experiences have been portrayed in nonfictional television narratives involves introducing new analytical frameworks and new questions as well as paying attention to new tensions. The tension between possible trivialization by television language and the medium's potential for dissemination is at once a crucial point of interest and a major difficulty for study of the link between collective memory and television.

\section{MEMORY AS AN OBJECT OF STUDY}

In both Argentina and other Southern Cone countries, many research works have lately made memory a center of gravity in the study of the recent past. These works have made important progress in reconstructing the political and social processes that occurred during the 1970s and 1980s in the region, interpreting the struggles of those periods and situating the actors and institutions involved in remembering and making others remember the suffering and violence experienced at the time. In addition to the variety of topics and approaches presented by this research, the study of memory is a fruitful area of debate, creating categories, developing methodological innovations, and building links between various disciplines. Such academic activity has a wide range of effects on ethical and political discussions about the recent past and on the shaping of public policies regarding memory (see the 12-volume series Memorias de la represión, edited by Elizabeth Jelin and published by Siglo XXI de España, the result of a training and research program carried out by the Social Science Research Council).

This field of study acknowledges, among many other influences, those that come from a sociology of memory, ranging from Maurice Halbwachs's pioneering works (1997 [1950]) on collective memory to Michael Pollak's research $(1990 ; 1993)$ on remembering extreme experiences and shaping identities in remembrance; from a history of memory, including the research of Pierre Nora (1984-1992) and Henry Rousso (1987) in France as an essential reference; and from a philosophy of memory that analyzes the dialectics between memory and oblivion, the nature of remembrance, the characteristics of historical consciousness, the "figures of wounded memory" (Ricoeur, 2000), and the problems associated with "abuses" and "excesses" of memory (Todorov, 1995). Another important line of work focuses on the idea of trauma and includes research carried out by psychoanalysts as well as historians and social scientists (among others, Caruth, 1996; LaCapra, 2009). 
Mainly since the mid-1990s, these works have been reread in the Southern Cone and have given rise to numerous investigations on social memory where the different approaches converge. In the Argentine field of debate and research, this subject has been taken up again in a specific regional context in which studies of memory aim, first, to help manage and process traumatic or painful experiences linked to violence and dictatorial repression and, additionally, to deal with the phase of democratic transition, attempting to differentiate the "democratic" present from the "authoritarian" past. In this context, research on memory aims not only to reconstruct the history of those years but also to analyze "the social process of remembering (and forgetting), studying their various layers" (Jelin, 2002: 2). Therefore, research on memory involves "pondering and analyzing the presence and meanings of the past in our societies," examining "the symbolic and material marks in which these remembrance processes are anchored."

This article is part of this field of study but with a special focus: to analyze the link between memory and television. Employing examples from the Argentine case, I will suggest three possible ways of investigating this link.

\section{TELEVISION AS AN ENTREPRENEUR OF MEMORY}

In 1995, there was a situation of impunity for the perpetrators who had abducted, tortured, and caused the disappearance of thousands of people in Argentina. After the laws of Punto Final (Full Stop, 1986) and Obediencia Debida (Due Obedience, 1987), and after the pardons granted in 1989 and 1990 to those tried and convicted, ${ }^{1}$ it seemed that the issue of the disappeared concerned only the actors directly involved. The mass media had stopped dealing with the issue, there were no major public events, and only the survivors, the human rights organizations, and the relatives of the disappeared were still working to have their accusations and demands for truth and justice heard. However, in March 1995 a seemingly minor event contributed to placing the topic once again in the public space and centering media attention on it. This was the statement of the former Navy captain Adolfo Francisco Scilingo, who had worked at the Escuela de Mecánica de la Armada (Naval School of Mechanical Engineering-ESMA) during the dictatorship. ${ }^{2}$ Scilingo narrated on a TV news program ${ }^{3}$ his part in the operations that consisted in dumping living detained-disappeared persons into the ocean from planes in flight. ${ }^{4}$ In this regard, he said that he himself had killed 30 people:

I participated in two aerial transfers, the first with 13 subversives aboard a Coast Guard Skyvan, and another with 17 terrorists in a Naval Aviation Electra. They were told they would be sent to a southern prison and therefore had to be vaccinated. They were given a first dose of anesthesia, which would be boosted by a stronger one in flight. Ultimately, in both cases, they were thrown naked into the South Atlantic waters from the planes in flight.

Although several statements had been made in previous years by military men regarding the crimes committed by the dictatorship, this was the first time that a perpetrator had recounted what he himself had done, without denials or 
euphemisms, and given details on the system of elimination of the kidnapped called the "death flights." In addition, this took place in front of television cameras. The protagonist of the events looked straight into the cameras and in this way sealed a pact of truth with the public. In the language of television, looking into the camera creates a unique contact with spectators in which the person speaking seems to be looking into their eyes. In this way, it functions as a "defictionalization" index, creating the meaning effect that the speaker is actually referring to "reality" and granting it a "type of 'proof' of the discourse's being anchored in the truth of the news" (Verón, 1983: 105).

The information Scilingo gave did not satisfy the longtime demands of the human rights organizations to know the truth about the clandestine repression. It did not help to determine what had happened to each disappeared person or who else was responsible for these crimes. However, the repercussions of Scilingo's statements were immediately felt: other television programs swiftly searched for unknown repressors in an attempt-not always successful-to have them "confess" before the cameras (Feld, 2009b). The issue of dictatorial repression entered the various media and became an unavoidable subject whose central premise was that there were unpunished crimes with victims, perpetrators, and a hidden violence that had to be brought to light. ${ }^{5}$ Scilingo's statements, made under the protection of impunity, powerfully combined with television languages, additionally had consequences that transcended the realm of the media: new avenues such as the truth trials (juicios por la verdad) opened up in the judicial system. ${ }^{6}$ The participation of new actors such as Hijos por la Identidad y la Justicia contra el Olvido y el Silencio (H.I.J.O.S.) ${ }^{7}$ was promoted, and new memorial sites such as the bank of the Río de la Plata in Buenos Aires City were established. ${ }^{8}$

Scilingo's statements did not take place in a vacuum. They coincided with a chronological distance of almost 20 years from the 1976 coup d'état, with activities that Argentine human rights organizations had been carrying out for quite some time, and with the issues related to memory raised by a new generation of young people (Valdez, 2001: 63-82). A few weeks later, the nineteenth-anniversary commemoration of the coup d'état received a boost and a massive response not seen in a long time (Lorenz, 2002: 21). In April 1996 Judge Baltasar Garzón began prosecuting some Argentine military men who had acted during the military dictatorship. Although Scilingo was protected in Argentina by the Obediencia Debida law, he was arrested in Madrid in 1997, and in April 2005 Spanish justice sentenced him to 640 years of prison for crimes against humanity, kidnapping, and torture. ${ }^{9}$

This brief survey shows the complexity of the task of collective memory and the unforeseeable ways in which remembering processes and actions regarding the past take place in societies that have gone through extreme experiences. Scilingo's televised statements did not immediately fulfill the expectations of truth and justice that they had generated. On the contrary, in a way it seemed that they strengthened this repressor's impunity, even showcasing it spectacularly. Nevertheless, in a dynamic that goes beyond this article and through various actors and political moments, these televised statements contributed to opening a "window of opportunity" for advancing the demands of the human rights organizations that had been fighting for many years in Argentina. This 
is the first link I would like to highlight between television and memory: in certain political and historical contexts, television can encourage the process called "overcoming the oblivion" of a past conflict period shrouded in silence.

This case was not the only one. We know that when the U.S. television series Holocaust (directed by Marvin Chomsky, 1978) was broadcast in Germany, it opened a debate on the Nazi past-on the degree of complicity of the German people in the extermination-and inspired a review of the topic by the new generations raised during the years of silence (Baer, 2006: 120-122). In the United States, the television coverage of Adolf Eichmann's trial while it was taking place in Israel in 1961 helped to instill "the notion of the Holocaust as an intellectual and ethical paradigm in American public culture" (Shandler, 1999: 107). However, in the Scilingo case it was not a matter of a fictional reconstruction of the facts through a television series or the broadcast of a trial. The event had taken place in a television studio as part of the construction of current events generated by this medium and was presented as a "revelation." As a medium that combined a wide reach, simultaneous reception, instant transmission, and a variety of expectations of truth established by a particular articulation of word and image, television made it possible to transform Scilingo's speech into a social and political event.

The actions of other "entrepreneurs of memory" contributed throughout the process, ${ }^{10}$ but television as an institution ${ }^{11}$ also took the initiative in bringing these topics into the public space and in this way television itself became an entrepreneur of memory. ${ }^{12}$ As of 1995 many journalists and producers of different ideological persuasions and different communication styles took the initiative to deal with state terrorism, attempting to create events, news, and actions about memory. They did this with varying objectives, including a mix of a particular conception of the duty of memory, eagerness not to be excluded from the journalistic "agenda," and the intent to increase ratings using a topic they thought was of interest to the public at large. ${ }^{13}$

What matters in this case is analyzing how television acts as a battleground between memories and the ways in which disputes about the past take shape in television space. Thus, this research approach allows for focusing on the struggles and conflicts among memories, considering collective memory as the object of "disputes, conflicts and struggles, which points to paying attention to the active role of the participants as producers of meaning in those struggles, in the framework of power relations" (Jelin, 2002: 2).

\section{TELEVISION AS A STAGE FOR MEMORY}

Work on memory requires more than just actors-persons or institutions in charge of developing memories, establishing representations of the past, and bringing their memorial enterprises to the public space. It additionally needs settings or stages where a presentation of and a discourse about the past are possible. These stages have their own rules and specific languages, which, in turn, determine the production of the accounts. Television is one of these stages for memory, and this is the second type of link between television and memory that I want to suggest. I call "stage for memory" the space in which a particular 
public is made to see and hear a "truthful" account of the past. The idea entails highlighting two characteristics of memory work: first the desire to create a pathway between a past that is considered finished and a present that is interpreted as different from that past (Ricoeur, 1999) and second the "truthful intent" of memory. As Ricoeur (1999: 29) states, the task of memory, in contrast to imagination, has exactness and fidelity as a goal, whether it achieves them or not. This calls for a process of construction and legitimation of a truth about what has occurred.

The idea of a "stage" - in contrast to other categories such as "realms of memory" (lieux de mémoire [Nora, 1984-1992]) or "conveyors of memory" (Rousso, 1987) -allows for focusing more clearly on problems related to the staging, dramatic tension, narrative devices at the service of the construction of meaning about the past, and mechanisms by which differing voices or testimonies are chosen, prioritized, and brought together. Therefore, in addition to probing the role of television as an "entrepreneur of memory" this approach analyzes the television programs themselves, including their formats and languages. ${ }^{14}$

The issue of how and with what language an extreme experience is narrated has created debates and raised questions in general societies, many of them about World War II and the Shoah. Regarding the audiovisual media, these debates include at least three principal dilemmas: one in the expressive order, about the appropriate language for portraying what occurred or, in other words, the limitations of language in depicting what is conceived of as "unimaginable," "unportrayable," etc., 15 a second in the ethical order, regarding how to avoid desecrating the memory of the event, trivializing it, or prolonging the horror by portraying it with images, among other issues; and finally one in the political order, focusing on the opportunities and political moments and on the political consequences of certain representations that enter the public space. ${ }^{16}$

Some of these dilemmas are in tension with the mainstream rationales of television communication, those that come into play regarding whether something appears on television or not. ${ }^{17}$ These rationales are that of the spectacle, which usually establishes formats and highly conventionalized language for television programs; the commercial rationale, which places on the small screen what is considered to be capable of increasing ratings; and the rationale of capturing an audience, which aims to attract the greatest possible audience for one program (the young spectator and the experienced one, the one who knows what happened and the one who has no information, the committed and the indifferent). It is true that these three rationales could transform the memory of an extreme experience into a show, a product for mass sale, and an allencompassing account that can be assimilated by everyone; however, these rationales also guarantee that a topic will be shown on television and seen by a broad public.

A study of informational genres (in particular, journalistic opinion programs and documentaries) broadcast by Argentine open television between 1995 and $2000^{18}$ (that is, in the five years after Scilingo's statements) reveals that, in general, these television narratives seem to obscure the nonspectacular aspects of the facts recounted, prioritize drama over historical understanding, and seek 
an emotional impact rather than political awareness. The images of these programs reduce the disappearances and the violence to a few traits, as something that affects the senses and appeals to the emotions. ${ }^{19}$ The ephemeral nature of television images, due to the fact that in the flow of television every new image tends to delete or to make invisible the previous one, ${ }^{20}$ is compensated for by the constant repetition of a few stereotyped images that end up becoming easily recognizable emblems. They are images that are not used to signal a specific referent but are used to go into the topic. They condense and symbolize various events, sometimes simplifying complex historical processes. For example, the image of the façade of the ESMA is used to evoke any one of the clandestine detention centers that operated around the country, symbolizing the notion of a clandestine center and the experience of captivity. In some television programs the witnesses are positioned at the door of the ESMA; in others it is the journalist who places himself there; in still others a camera roves around the place without showing people. Although we know that the torture and captivity took place mostly in another ESMA building called the "Officers' Casino," that location remains invisible: the images-for the most part-show the front of the four-columned building about 200 meters away. Similarly, images of the faces of some of the well-known military men-such as Emilio Massera, Jorge Rafael Videla, and Alfredo Astiz-serve to compress the general category of "perpetrators," and they function as interchangeable icons without any explanation of the specific responsibility of any of them..$^{21}$ They are images that can fix a memory, make it somehow "stable" and accessible to the public. While they successfully transmit that narrative, these formats and languages seem less likely to provide a complex version of history, raise questions, propose lines of action for the future, or politicize the link with events of the past. ${ }^{22}$

In short, the analysis of these television programs and approaching television as a stage for memory allow us-among other lines of inquiry - to reflect on the relationship and tension between image and historical truth, between spectacle and collective memory, and to think about how the duty of memory and the obstacles to recounting an extreme experience end up combining with the intent to sell a product and entertain a spectator in a complex, nonlinear fashion that is not always easy to understand.

\section{TELEVISION AS A VEHICLE OF INTERGENERATIONAL TRANSMISSION}

Television is one vehicle of transmission to the new generations, among many others: formal education, the family sphere, other cultural consumption, social networks, youth culture spaces, communication technologies, etc. This kind of approach should therefore observe the differences as well as the interaction among all these spheres and media. In this framework, television has certain specific characteristics: immediacy, easy reading, emotional potential, mass reach, home consumption, deep reach into all social strata, and impact on youth. In 2000 I carried out in-depth interviews with a small number of young people from Buenos Aires City who were born between 1976 and 1979 (that is, during the first three years of the military dictatorship). They were students in 
various university and postsecondary majors of various social extractions and family histories. None of the students had been direct victims of the repression or were relatives of the disappeared, and none belonged to military families. At the time of the interviews, they were between 21 and 24 years old, and because of their age they did not have any memories of their own of what had happened during the dictatorship. Therefore, their "memory" combined recollections of what had been transmitted to them by various means and at different points in their lives with interpretations of what had occurred that they had developed as adults. These young people had reached legal age around 1995, at the time when the issue of dictatorial repression was again being raised as a result of Scilingo's statements. ${ }^{23}$ Although the interviewees do not make up a representative sample and therefore the interviews cannot give us conclusive data on the role of television in the work of transmission, they do provide some clues I would like to describe.

Because of the ways these young people constructed their accounts about the dictatorship and the elements they brought with their evocations, we can infer that television had given them narrative clues for interpreting history. Those clues allowed them to relate what had happened to their own experience, although their accounts did not always coincide with the historical truth. ${ }^{24}$ Their accounts were based on depoliticizing the disappeared-the idea that disappearance had been a mass phenomenon that could have happened to anyone and the belief that many had been captured only because their names were in an address book. Some interviewees referred to the fear felt at that time but without a concrete explanation of who was afraid and why. In general, if they mentioned the activities of the persons who disappeared, they said that the disappeared had different ideas or were opposed to the dictatorship:

In those days everything was so unsafe that you couldn't even go out to the streets, something like that; you stuck your head out of the window and they'd grab you, they'd take you away. They were very tense times. [Darío] ${ }^{25}$

The disappeared are those who, on the one hand, dared to express those different ideas, or those who, without daring, tried to get those ideas out to people. ... The disappeared are maybe ... people who were in the wrong place at the wrong time. [Ramiro]

They belonged to a political party or had a different political idea than they [the authorities] did . . . or just having your name somewhere, connected to somebody they knew had a certain ideology, so because you were in someone's address book, you were finished. [Maximiliano]

I don't know, maybe what is most revolting is that they were people who were in school or who didn't agree. It's something that today, what a crazy thing, how can they do all those things to someone because they think differently? [Nicolás]

In the context in which the interviewees recounted their experiences, the idea that "it could have happened to anyone" helped them in identifying with the victims. They said, for example, that young people their own age had disappeared, that they might have thought the way the disappeared thought, etc. In 
a setting of depoliticizing and discrediting political activity such as Argentina in the 1990s, this narrative clue also served to promote the idea that politics was dangerous and that, ultimately, political activism did not entail anything more than "thinking differently." Any notion of political commitment, social activism, or even transforming society through politics was thus eradicated from the vision linked to the repression in the 1970s. These ideas were deeply rooted in Argentine common sense at the time of the interviews and had been transmitted for years through various cultural productions and public speeches. ${ }^{26}$ But these ideas were also the core of most television narratives, especially of the programs that the interviewees said they had seen. From the interviews we can infer that television had also provided them with elements for managing their emotions in the face of these events. Most of the accounts included in these interviews respond to a very common emotional code in programs of the time: shock, outrage, and helplessness are some of the feelings evoked in the interviews regarding the topic of the disappeared. However, in the discourse of these young people those feelings were not always attached to information about what caused them. The distance between what they felt (or said they felt) and what they knew (or said they knew) was striking. Some even mentioned the lack of information and said that they had a "blur" or a very vague idea about the history:
All of this still horrifies me, but now I think I need to clear up this blur that I have, categorize all those names and common places that I have in my head, but I can't, I can't classify them properly; I have names but I don't have titles, I don't have facts straight, you know? I have things floating around and a lot of outrage and helplessness. [Abel, emphasis mine]

But television has also served them as a trigger for memories, especially if they watched the programs with their parents or other adults. As pointed out above, they often spoke of things that had happened "around" them or that "could have happened to anyone" without much detail about specific cases. However, when they spoke of television programs and of the conversations they had had with adults while watching the programs, recollections of people and concrete stories began to emerge. This happened, for example, with one of the interviewees in our second meeting, when we watched a recorded television program as part of the interview. When asked "What are the things that affect you most [in the program viewed], or how do they affect you?" Abel responded,

The testimonies of the detained and of the children. . . I d don't know, it was really shocking for me, because ... because, well, those boys and girls are my age, or about my age, and ... I don't know, they've taken people ... my mother's age too ... well, I don't know. Look, one of the testimonies reminds me a lot of the case of a man who recently went to ... my mother is a hairdresser, he went to get his hair cut, and I was there, and he said that they had kidnapped him and tortured him ... and ... that really got to me, and now it reminded me of that, one of these cases, because the guy looked like him.

Lastly, we can conclude that television programs-and also some movies released at the time, such as Marco Bechis's 1999 Garage Olimpo-provided 
these young people with images to illustrate these events and make them "visible" and "tangible." In their references to these images, the scenes reconstituted by the television programs are sometimes confused with archival film images and what "is seen" is described as something that actually happened, as images that belong to the past. For example, when Scilingo's first statements came out, many television news shows aired footage of military planes in flight, which obviously was not archival footage (since the flights were secret and clandestine crimes) but rather recreated or merely illustrated the "death flights." 27 In the interviews, those same images were recalled by these young people as if they had seen what "really" happened during the dictatorship through them. They say, "I saw the planes" or "They show the planes":

Yes, I don't know if on TV, I don't really remember the first time I heard, but ... but I do know that it wasn't something that someone told me specifically; I know I found out somewhere and I asked my parents, what it was, you know, what the coup d'état was. I don't really know much about it, I mean, I know more or less. Uh ... well, and ... what the disappeared were, and lately I did see a lot on television that showed the planes, I mean, I do know that. But . . . but I don't really remember much. [Mariela, emphasis mine]

The video shows images, while they're in the trial, it shows images from the dictatorship, and when they talk about the transfer or that they're going up it shows images of the planes. [Carolina, emphasis mine]

In addition, the images I have described as "emblematic" in the analysis of the programs appear repeatedly in the accounts of these young people. For example, when they refer to the perpetrators, they name the two or three people whose faces usually appear as stereotyped images on television, without distinctions between them or details on their different responsibilities within the dictatorship:

Videla, Massera, everyone more or less the same, yes, they are all part of that issue and, well, they are all involved with the issue of the disappeared, all lumped together. [Mariela]

I think Astiz was in the Navy, I think that Massera, I suppose he was part of the military ... and I don't know if Videla was also in the military. I know Videla had, like, a higher rank than the rest. He was, I think, was one, let's say, of the initiators and proclaimers and leaders of the whole Military Process, and that's all I can tell you. [Maximiliano]

It is clear that television reception is intertwined with the reception from other cultural products and means of transmitting memories, and it is also clear that we cannot establish which of these media is linked to which memory. Moreover, we know that the televised accounts were shaped by narrative clues that already belonged to common sense or to certain hegemonic narratives established by other cultural products and public discourses. Even so, we can be sure that in the period we are analyzing, television helped to bring references from the past closer to a youthful public - to make the history "visible" and to generate more vivid emotions regarding what happened. 
Overall, television programs have probably contributed to creating an interested public. However, according to the aforementioned interviews, that interest seems to be more a general concern about the topic or an emotional involvement than an intellectual or even political involvement, that is, the kind of interest that could lead to action. In this sense, we could rightly ask to what degree these vehicles of transmission allow the historical experience to be linked to the presence experience. As Andreas Huyssen (2002: 164) states with regard to the memory of the Holocaust, "The future will judge us not for forgetting but for remembering it all and, even then, not acting in accordance with those memories."

\section{IN CONCLUSION}

Constructing a link between memory and television opens up a broad field of exploration of various processes that have not been deeply considered by the classic studies on collective memory (Halbwachs, 1997 [1950]; Nora, 1984-1992; among others). Those processes are related to expressions that concern the contemporary culture of memory, memory as a mass phenomenon, and the current modalities of remembering, given that television in particular and audiovisual media in general play a central role in these processes.

In contrast to the classic studies on collective memory, my study has been based on the premise that the media and tangible means of transmission of memory not only preserve the footprints of the past and transmit them from one era to another but also help shape the accounts and representations of the past that are projected into the public space. The study of the vehicles of memory (ranging from monuments to the press, including film, television, or the Internet) does not consider these vehicles merely as a source for reconstructing the past but as a specific object of analysis-keeping in mind that they were built with special rules and rationales, at particular moments, and as a result of concrete choices and strategies. Specifically regarding television, various approaches can be adopted for research depending on what we wish to highlight: the role of this medium in the formation of public agendas (that is, as an entrepreneur of memory), its effectiveness as a means for transmitting events of the past to the new generations (a vehicle of transmission), or its role as a builder of meanings through images, sounds, and words (a stage for memory). These roles, of course, coexist and are intertwined in ways that should be explored more thoroughly, but the analytical distinction can help advance the research on a still little-studied object.

I would like to conclude by pointing out some tensions that arise from linking these three roles. It seems that the languages of television shows that lead to an emotional involvement and exclude the development of more complex aspects of the narrated history, making political analysis difficult, are the same languages that help to generate an interested public, to communicate the existence of memorial enterprises, to legitimize some voices previously silenced, and to produce empathy about the topic in the younger generations. Nevertheless, in identifying certain events from the past as a public problem (Edelman, 1991) television can also help to open a window of opportunity for actors already involved, thus fostering and articulating the actions that some entrepreneurs of memory had already been taking separately or without 
extensive public dissemination. I insist on the fact that, in the development and building of collective memories, not only television but also the entire memorial process, the diverse vehicles for memory and the actors involved, should be considered. However, we cannot ignore the enormous potential of television communication in the current processes of construction of memories. Production of television spectacle can therefore additionally be memorial production. But what type of memory is helping to configure this medium, with its communication based on images and emotions? What is the relationship between television, memory, and politics? In what ways does television contribute to the complex memory process that helps societies to overcome their traumatic experiences? These are some of the questions that arise from the experience on the use of television in Argentina, especially between 1995 and 2000, and that should be included in a more complete research agenda.

\section{NOTES}

1. The law known as Punto Final set a 60-day deadline for the initiation of suits against the repressors. That of Obediencia Debida exempted the majority of the military accused of responsibility for the crimes committed, even some who had already been found guilty, by creating an immediate presumption that they had been carrying out orders from their superiors. In 1989 and 1990 then-president Carlos Menem pardoned and released all the military and police who were being tried or serving sentences for human rights violations under the military dictatorship.

2. The ESMA, located in the city of Buenos Aires, was one of the most active clandestine detention, torture, and extermination centers during the dictatorship. It is estimated that 5,000 detainees went through there and about 200 survived.

3. The March 9, 1995, Hora Clave, hosted by Mariano Grondona, a conservative Catholic journalist linked to previous military regimes. In the 1990s Grondona tried to distance himself from that past by taking a position in defense of democratic institutions.

4. After submitting those abducted to physical and psychological torture, the military eliminated them by tossing them unconscious from planes into the sea or executed them and later hid their bodies by burning or burying them in common graves (see CONADEP, 1984: 235-237). The televised Scilingo statements had been taped the day before and were presented as a continuation of the previous week's program, in which Grondona had spoken with the journalist Horacio Verbitsky, author of El vuelo (1995), which was based on a long interview with Scilingo.

5. In the months following Scilingo's statements, the issue of the disappeared and, more broadly, the repression under the dictatorship - which had been largely absent from the mass media since the early 1990s-began to take up hours of programming and entire pages in newspapers and magazines. Some of the topics dealt with by the media during those months were the question of the fate of the disappeared, derived from the request of the Ministry of Justice for lists from the government and the armed forces; the controversial role of the Catholic Church during those years; the fate of the children of the disappeared (one of whom was returned to his biological family in 1995 while his kidnappers were arrested and tried); the search for Jorge Bergés, the doctor who participated in torture sessions and had escaped from the capital police; and the much-disputed possibility of the promotion of then-Captain Astiz, in addition to the statements of reference of the repressors and the televised "message to the country" of Lieutenant General Martín Balza referring to the disappeared (see La Nación, Clarín, and Página/12, March-July 1995).

6. One of the immediate repercussions of Scilingo's statements was the demand by the Justice Ministry and some human rights organizations for the military documentation that this repressor had mentioned. Those documents never appeared, but on April 8, 1995, the Centro de Estudios Legales y Sociales (Center for Legal and Social Studies-CELS) asked the federal court in Buenos Aires to acknowledge "the right to the truth and to mourning by the relatives of the disappeared." This initiative paved the way for the "truth trials," whose primary objective was not to punish those responsible (protected at the time by the Punto Final and Obediencia Debida laws) but to reconstruct the facts of each case. In the years that followed, these trials were replicated in various 
cities around Argentina, and some sent former military men to prison for false testimony or refusal to testify.

7. H.I.J.O.S., founded in 1995, brings together children of "the kidnapped, tortured, assassinated, disappeared, survivors of prisons, or those who had to flee into exile, and those who feel directly affected by the political repression in Argentina" (http://www.hijos-capital.org.ar). According to the organization, its growth was spurred by the television statements of Scilingo: "In April 1995 [sic] Scilingo shows up, a military man who publicly confessed what the victims of the dictatorship had said years before. This shocked the nation, and HIJOS began to appear in the press and on television to present their position. People saw us on TV, and other children also saw us on TV. More and more members starting arriving-from the 8 that started meeting in the capital, a week later there were 30 . When the second camp encounter was held, HIJOS already had more than 350 members, from 14 regional groupings around Argentina" (http://www.hijos-capital.org.ar/ index.php?option=com_content\&view=article\&id=19\&Itemid=400 (accessed May 24, 2013).

8. A few days after Scilingo's statements, on March 30, 1995, the first tribute to the disappeared was held in the promenade by the Río de la Plata banks, where "a moving ecumenical religious service [was held] that ended with those in attendance throwing flowers into the river, the final destination of a great number of the disappeared" (Valdez, 2001: 71). The organizers acknowledged that the location chosen had to do with Scilingo's statements about the flights (Página/12, March 31, 1995).

9. The cracks in impunity created in the mid-1990s widened in a very different political context some years later, with the presidency of Néstor Kirchner. In 2003 the Congress annulled the Obediencia Debida and Punto Final laws as unconstitutional, and many of the trials closed down in 1987 were able to be reopened. Currently, hundreds of repressors are being tried in various courts around Argentina, and many have already been found guilty. For more information on the progress of these trials, see http://www.cels.org.ar/wpblogs/ (accessed May 24, 2013).

10. "Entrepreneurs of memory" are persons or groups that "seek social acknowledgment and political legitimacy of a (their) version or account of the past. They also work for and are concerned with keeping social and political attention to their endeavor visible and active" (Jelin, 2002: 49).

11. When referring to television as an "institution" I take into account the multiple levels of enunciation on television, because several agents can be found there. In a very general way, in Argentine television news programs enunciation is placed in a plurality of voices or levels involving the medium, producers, presenters, and the protagonists of the events, which carry different weight and decision-making power depending on the situation (the channel, political moment, and type of information, among other things).

12. In the 1980s and early 1990s there was virtually no sustained initiative by television to deal with the disappeared. This topic appeared on television only when some "news" was produced in other institutional spheres (politics, the military, the judiciary, human rights organizations, etc.) Starting in 1995, the institution of television acquired new legitimacy as broadcasters and television programs began to present the issue in their own formats (see Feld, 2006).

13. This section is based on interviews with producers of television programs and documentaries between 1998 and 1999 .

14. My analysis of "stages of memory" has at least three dimensions: narrative (telling the story), dealing with the type of account and the codes used to tell the story; dramatic (staging), dealing with the language and other elements used in the staging matter; and truth, dealing with the type of truth about the past involved.

15. As Anton Kaes (1992: 208) has stated, this dilemma could be defined as follows: "If we accept that the massive, catastrophic destruction that occurred fifty years ago challenges not only the historical description and the quantitative determinations but also the rational explanation and linguistic expression, then a new self-reflexive means of codifying history is needed."

16. For example, in France the representations of the deportations that made it into the public space in the years immediately after World War II were almost exclusively focused on the resisters, leaving aside the "racial" deportees-not recognizing the singular nature of the genocide of Jews and Gypsies. This is explained in part by the fact that, politically, it was better to establish a type of memory that would serve to reunify France, a heroic memory of what happened during the occupation (see, among others, Rousso, 1987; Wieviorka, 1992).

17. These considerations refer in particular to Argentine television, which has been mostly private and commercial, especially during the period analyzed in this essay (see Colombo, 1976; González Requena, 1988). 
18. For more in-depth treatment, see Feld (2006; 2009a). Informational television genres were chosen because they were more numerous than fictional genres in communicating this topic. Only in the early 2000s did fictional programs and television dramas begin to appear that dealt with the issue of the disappeared and, in particular, the children illegally taken by the military.

19. The richness and variety of the work with images in documentary films of the same period can be contrasted with the more standardized resources that I have just mentioned (see Amado, 2009).

20. As Michèle Lagny (1991: 72) explains, "In the flow of images, the last representation erases the previous ones: film reproduction does not follow a logic of accumulation but one of the passage; this is not just a result of the flow of the film-image, but its very principle."

21. Emilio Eduardo Massera (a navy commander) and Jorge Rafael Videla (an army commander) were the main members of the military junta that took power in 1976 and received life sentences in the 1985 trial (pardoned in 1990). Alfredo Astiz, who was a frigate lieutenant during the dictatorship, participated in the ESMA abduction operations. In 1977 he infiltrated the first group of the Mothers of Plaza de Mayo and caused the disappearance of several of them in addition to two French nuns who were part of the group. He was released under Obediencia Debida but tried again with the reopening of the trials in 2005 and sentenced to life imprisonment in 2011.

22. These observations follow from the analysis of two television documentary series produced between 1998 and 1999 by two independent producers for private and commercial air channels. The first consisted of two programs produced by the journalist Magdalena Ruiz Guiñazú for Channel 13: "ESMA: El día del juicio" (ESMA: Judgment Day, August 24, 1998) and "El día después" (The Day After, December 15, 1999), both shown at 11 p.m. The second, Punto.doc, produced by Cuatro Cabezas and hosted by the journalist Rolando Graña, consisted of 11 programs aired between October and December 1999 by Channel 9 in the 11 p.m. time slot. Three of them had the issue of the dictatorship's repression as the central theme: "Condor.Doc," aired on October 20, 1999, "Hijos.Doc," shown on November 3, 1999, and "Generales.Doc," aired on December 15, 1999 (at the same time as the broadcast of "El día después"). A more detailed analysis of these programs can be found in Feld (2009a).

23. I carried out two in-depth interviews with each of the 10 interviewees (5 men, 5 women). The first interview was a "life history" that used as a central element their relationships with the repression-what memories they had, what they thought had affected them most, what they thought about the channels they received information from. In a second part of that first interview, the accent was placed on the relationship between those memories and the contacts they had had with audiovisual materials that evoked the subject of the repression either in the past or in recent years. The second interview used the showing of a television program as the starting point. The program chosen was "ESMA: El día del juicio" (aired on Channel 13 in August 1998). The research work was financed through a doctoral scholarship from the Instituto de Desarrollo Económico y Social (Institute of Economic and Social Development-IDES).

24. This dissociation between memory and historical truth has also been highlighted by Susana Kaiser (1998).

25. The names have been changed in order to protect the identity of the interviewees.

26. Among those with the greatest impact and the most widely known were the 1986 film $\mathrm{La}$ noche de los lápices (Night of the Pencils, directed by Héctor Olivera) and the prologue of the Nunca Más (Never Again) report (CONADEP, 1984). Although the view of the disappeared as activists began to appear in books and movies in 1996, it came to television much later, in the period after 2003, after Néstor Kirchner became president, in the context of a policy and government discourse that extolled activism and the political actors of the 1970s, considering them a generation of struggle.

27. On television the words of these repressors are illustrated with "reconstituted" images of aerial photos over the sea, of military planes in flight, or by shadows of military planes over a reflection on water. These images continued to be used, both in news genres and in fiction, not only in television but also in movies.

\section{REFERENCES}

Amado, Ana

2009 La imagen justa: Cine argentino y politica (1980-2007). Buenos Aires: Colihue.

Baer, Alejandro

2006 Holocausto: Recuerdo y representación. Madrid: Losada. 
Calveiro, Pilar

1998 Poder y desaparición: Los campos de concentración en Argentina. Buenos Aires: Colihue.

Caruth, Cathy

1996 Unclaimed Experience: Trauma, Narrative, and History. Baltimore, MD: Johns Hopkins University Press.

Colombo, Furio

1976 Televisión: La realidad como espectáculo. Barcelona: Gustavo Gili.

CONADEP (Comisión Nacional sobre la Desapareción de Personas)

1984 Nunca Más: Informe de la Comisión Nacional sobre la Desaparición de Personas. Buenos Aires: EUDEBA.

Delage, Christian

2007 La vérité par l'image: De Nuremberg au procès Milosevic. Paris: Denoël.

Drame, Claudine

2007 Des films pour le dire: Reflets de la Shoah au cinéma (1945-1985). Geneva: Metropolis.

Edelman, Murray

1991 La construcción del espectáculo político. Buenos Aires: Manantial.

Feld, Claudia

2006 "Quand la télévision argentine convoque les disparus: modalités et enjeux de la représentation médiatique d'une expérience extrême." Les Temps des Médias 6 (Spring): 188-202.

2009a "Aquellos ojos que contemplaron el límite: la puesta en escena televisiva de testimonios sobre la desaparición," pp. 77-109 in Claudia Feld and Jessica Stites Mor (eds.), El pasado que miramos: Memoria e imagen ante la historia reciente. Buenos Aires: Paidós.

2009 b "Entre la visibilidad y la justicia: los testimonios televisivos de represores en la Argentina." Encuentros Uruguayos 2 (November): 42-57.

Friedlander, Saul (ed.).

1992 Probing the Limits of Representation: Nazism and the "Final Solution." Cambridge, MA, and London: Harvard University Press.

González Requena, Jesús 1988 El discurso televisivo: Espectáculo de la posmodernidad. Madrid: Cátedra.

Halbwachs, Maurice 1997 (1950) La mémoire collective. Paris: Albin Michel.

Hansen, Miriam Batu

2001 "Schindler's List is not Shoah: second commandment, popular modernism, and public memory," pp. 127-151 in Barbie Zelizer (ed.), Visual Culture and the Holocaust. New Brunswick, NJ: Rutgers University Press.

Huyssen, Andreas

2002 En busca del futuro perdido: Cultura y memoria en tiempos de globalización. Mexico City: Fondo de Cultura Económica.

Insdorf, Annette 1985 L'Holocauste à l'écran. CinéMaction 32.

Jelin, Elizabeth 2002 Los trabajos de la memoria. Madrid and Buenos Aires: Siglo XXI Editores.

Kaes, Anton

1989 From Hitler to Heimat: The Return of History as Film. Cambridge, MA, and London: Harvard University Press.

1992 "Holocaust and the end of history: postmodern historiography in cinema," pp. 206-222 in Saul Friedlander (ed.), Probing the Limits of Representation: Nazism and the "Final Solution." Cambridge, MA, and London: Harvard University Press.

Kaiser, Susana 1998 "Memorias y amnesias: how do Argentineans remember the dictatorship?" Paper prepared for the 1998 meeting of the Latin American Studies Association.

Koch, Gertrude 1990 "Transformations esthétiques dans la représentation de l'inimaginable," in Claude Lanzmann and others, Au sujet de Shoah: Le film de Claude Lanzmann. Paris: Belin.

LaCapra, Dominick 2009 Historia y memoria después de Auschwitz. Buenos Aires: Prometeo. 
Lagny, Michèle

1991 “L'histoire contre l'image, l'image contre la mémoire." Hors Cadre (Le Cinéma à travers Champs Disciplinaires) 9 (Spring): 63-76.

Lorenz, Federico

2002 “ ¿De quién es el 24 de marzo? Las luchas por la memoria del golpe de 1976,” pp. 53-100 in Elizabeth Jelin (ed.), Las conmemoraciones: Las disputas en las fechas "in-felices." Madrid and Buenos Aires: Siglo XXI Editores.

Nora, Pierre (ed.).

1984-1992 Les lieux de mémoire. 3 vols. Paris: Gallimard.

Pollak, Michael

1990 L'expérience concentrationnaire: Essai sur le maintien de l'identité sociale. París: Editions Métailié.

1993 Une identité blessée: Études de sociologie et d'histoire. París: Editions Métailié.

Pollak, Michael and Nathalie Heinich

1986 "Le témoignage." Actes de la Recherche en Sciences Sociales 62-63 (June): 3-29.

Ricoeur, Paul

1999 La lectura del tiempo pasado: Memoria y olvido. Madrid: Ediciones UAM.

2000 La mémoire, l'histoire, l'oubli. París: Seuil.

Rousso, Henry

1987 Le syndrome de Vichy, de 1944 à nos jours. Paris: Seuil.

Shandler, Jeffrey

1999 While America Watches: Televising the Holocaust. New York and Oxford: Oxford University Press.

Todorov, Tzvetan

1995 Les abus de la mémoire. Paris: Arléa.

Valdez, Patricia

2001 “Tiempo óptimo para la memoria," pp. 63-82 in Bruno Groppo and Patricia Flier (eds.), La imposibilidad del olvido: Recorridos de la memoria en Argentina, Chile y Uruguay. La Plata: Ediciones Al Margen.

Verbitsky, Horacio

1995 El vuelo. Buenos Aires: Planeta.

Verón, Eliseo

1983 “Il est là, je le vois, il me parle." Communications 38: 98-120.

Wieviorka, Annette

1992 Déportation et génocide: Entre la mémoire et l'oubli. Paris: Plon. 